\title{
Beyond obsolescence: A twenty-first century research agenda for the
}

\section{langues régionales}

\author{
DAMIEN HALL ${ }^{\mathrm{a}}$ \\ JONATHAN R. KASSTAN ${ }^{b}$ \\ DAVID HORNSBYc \\ $a_{\text {Newcastle University }}$ \\ ${ }^{b}$ University of Westminster \\ ${ }^{c}$ University of Kent
}

'It is fair to say that variationist sociolinguistics as a whole has not been energetically engaged with underrepresented languages'. This clarion call by Stanford (2016: 526) sums up in a few words our rationale for bringing together the studies presented in this volume. Among all underrepresented languages, we believe that the French langues régionales (as defined by the Ministère de la Culture, 2018; henceforth LR) show particularly well why variationist sociolinguistics would profit from greater engagement with such varieties. This is why we proposed to the Journal of French Language Studies a volume in which not a single article on French itself would appear. We are, temporarily, interpreting the French in the journal title as meaning 'found in France', and we are grateful that the journal editors for agreeing to a temporary reinterpretation we felt timely and necessary. Barely a generation ago, academic discussion of France's regional languages rarely ventured beyond a lament for their impending demise, but, a combination of factors, from the advent of the European Charter for Regional or Minority Languages (still unratified by the Republic, $c f$ most recently Harrison and Joubert, 2019; Roger, 2019) to new communication media, diversified speaker bases, and theoretical 
and methodological advances, have awakened new scholarly interest in these varieties from a wide range of perspectives. In compiling a volume on this particular topic, we were especially mindful of six key themes, which we enumerate below, and to which our contributors have energetically responded.

\section{VARIATIONIST SOCIOLINGUISTIC WORK SHOULD BE DONE ON MORE}

\section{LANGUAGES}

Variationism as currently understood began, in a sense, with regional languages in francophone Europe. Gauchat's (1905) apparent-time study of Francoprovençal as spoken in the Swiss village of Charmey is frequently lauded as a pioneering piece of sociolinguistic research (see e.g Labov, 1994: 85-86; Chambers, 1995: 15-16). ${ }^{1}$ Gauchat's work was significant enough to merit a real-time follow-up study by Hermann (1929), but since the variationist turn of the late 1960s attention has been focused predominantly on the anglophone world. Stanford (2016) is the clearest recent call to action for variationist sociolinguistics to move beyond the English data on which it was mostly born.

There are exceptions to the English generalization, of course. Stanford mentions Sankoff and Cedergren's pioneering early work in Papua New Guinea (Tok Pisin), Panama City (Spanish) and Montreal (French) (Sankoff, 1980 [1976]; Cedergren, 1973; Vincent, Laforest and Martel, 1995). There is also recent variationist work on endangered languages besides Stanford (2016): Stanford and Preston (2009) and Hildebrandt, Jany and Silva (2017) are good recent examples. The journal Asia-Pacific Language Variation, founded in 2015, now regularly publishes articles on threatened and lesser studied languages alongside dominant ones such as Mandarin and Japanese. However, recent surveys of the sorts of language communities

\footnotetext{
${ }^{1}$ While Labov (1994: 141) refers to the 'Romance dialects' of Charmey, Chambers (1995: 16) describes the patois of Charmey as a 'French vernacular'. However, the features outlined in Gauchat (1905) are definitively Francoprovençal and not (regional) French: e.g palatalization of laterals before obstruents, tensing of Latin wordfinal A etc.
} 
studied in our flagship journals and conference series ( $c f$ Nagy and Meyerhoff, 2008; Guy and Adli, 2019) demonstrate that monolingual speakers of dominant European languages remain the bedrock on which our sociolinguistic theorizations are based (e.g Bell, 2016; Meyerhoff et $a l$, fc.).

Of course, 'working with other languages' is not as simple as taking a template developed largely on English and fitting the data from other languages into it. When variationists move out of the modern developed-world English-speaking cities in which their universities are likely to be found, and seek to apply their techniques to underrepresented languages, there are very likely to be social challenges as well as linguistic ones (Labov, 2015; Meyerhoff, 2017; Chirkova et al, 2018). Underrepresented languages are rarely found either in cities or in the developed world, and are consequently unlikely to follow variationist models developed for use in modern, urban societies with established social hierarchies. Labov himself has warned against such assumptions (2016: 586):

Though my New York City study was generally well received, I noted in the years that followed a tendency to regard it as a claim that class stratification of linguistic variables, measured by occupation, education and income, would be found everywhere in the world. Of course, no such claim was intended. In fact, I often wondered whether the techniques we had developed for the study of variation in the Western metropolis, measuring, comparing and counting the use of variants over time, would have any application to the study of little-known languages where the linguist is under an imperative to describe the basic elements and structures before the object of description disappears. Small differences in vowel quality or suffix realization might have to take second place to the description of major constituents. 
Low speaker numbers, as Müller (2011a) points out, pose a further challenge, as does the linguistic heterogeneity which often accompanies the absence of an accepted, codified standard. These factors also cast serious doubt over the usefulness of the statistical tests common in variationist research, because in general - for multivariate analysis, logistic regression and even a simple chi-square test - the more tokens, the better, and modelling can fail or mislead if token numbers are too low.

However, as this volume demonstrates, these social and statistical challenges are not insuperable, and if linguists are willing to take up the challenge of overcoming them, the rewards can be great (as Labov, 2015 and Meyerhoff, 2017 have argued). A number of articles in this issue have necessarily had to adapt traditional variationist research designs for new contexts, and this has meant grappling with issues such as sample representativity and low token counts. Burnett's article for instance uses historical data from the Atlas linguistique de la France (Gilliéron and Edmont, 1902-1910) to test the hypothesis that variable mie-dropping (i.e secondary negation) in moribund northern oïl varieties can be shown to be conditioned by the same sorts of probabilistic factors that constrain morpho-syntactic variation in synchronic studies. She demonstrates that generalized linear mixed-effects modelling can be used in spite of the atlas' very small and highly variable sample of the phenomenon she investigates. Her work echoes Trudgill (1999: 319) in reminding us not to ignore low token counts; in this case a small sample can be rigorously investigated to establish what social life of language may yet be explored in the historical record, thus also contributing to the relatively young field of historical sociolinguistics.

\section{THEORIES SHOULD BE TESTED ON OTHER LANGUAGES}

Since Chomsky (1967: 7) at least, linguistics has generally held its theories to be 'systems of hypotheses concerning the general features of human language'. It follows from this that the 
theories should be tested on the widest possible range of languages, to get as close as possible to explanatory adequacy in Chomsky's terms. For many years from the beginning of generative linguistics, however, theories tended to be formulated on English or another major language of the Western world, and not explicitly tested on lesser known language. This Special Issue is broadly sociolinguistic in orientation, and our contention as editors is not simply that excessive anglocentrism in sociolinguistics is limiting and dangerous, though this is undoubtedly the case (as others have argued, e.g Smakman, 2015). We also feel a Special Issue on the LRs is timely because these languages raise questions of a different order from those of the major, standardized languages with which linguists happen to be most familiar, and which, as Trudgill (2011) has pointed out, are historically atypical on a number of levels. Far from being outliers of little theoretical interest, minority, threatened languages spoken in peripheral areas within modern nation-states, often with a longer historical pedigree than their more powerful neighbours, are precisely where the sociolinguist's attention should be directed. And yet, while the birth of the Journal of French Language Studies in 1991 testified to a desire to focus scholarly attention on languages other than English, minority languages are still only rarely the objects of theoretical reflection. This was enough of a problem that Smith and Maiden (1995: $\mathrm{x})$ felt it necessary to point out that their volume, Linguistic Theory and the Romance Languages, was an exception to the rule. Fortunately, in recent years, LRs have been the subject of a growing amount of theoretical and instrumental work which explicitly seeks to integrate findings about them into our cross-linguistic knowledge.

Picard, the subject of two contributions to this volume, is the LR which has perhaps contributed most to advancing linguistic theory. This is especially true in phonetics and phonology, starting with the work of Fernand Carton from the 1970s onwards (e.g Carton, 1981). In recent years, Julie Auger, the co-author of a contribution to this volume, and her many collaborators and students have been working with Picard to both test and advance 
theorizations in linguistics, both in 'phon-phon' (e.g Hendrickson, 2013; Dow, 2014) and in other areas, particularly the separation of closely-related grammars (Auger and Villeneuve, 2008; Villeneuve and Auger, 2013).

A phonetic category which has received considerable attention in the LR literature recently is that of the laterals, particularly in relation to Occitan and related varieties (e.g Müller 2011a, b). In the current volume, Mooney and Hawkey identify a merger of the palatal lateral approximant $/ K /$ and the median approximant $/ \mathrm{j} /$ in both Occitan and Catalan, which they diagnose through a synchronic analysis of variation between the two variants. The study of this merger in the context of language contact is fruitful, as French underwent the merger in the 19th century, and so the context provides fertile ground for comparative sociolinguistic analysis. In this study, the authors ask whether the change can be attributed to contact effects, or whether it is in fact internally motivated, given that $/ K />[\mathrm{j}]$ is commonly attested in Romance (see e.g Wheeler, 1988). Interference of the kind studied in that work, between closely related but independent L1 and L2 phonological systems, can only be explored in the context of contact between a dominant language and a dominated one, of which France, with its long tradition of linguistic centralism, offers plenty of examples.

France's LRs also offer fertile ground on which to test and better understand advancements in phonetics and phonology from a diachronic perspective. While a study in historical phonology rather than variationist sociolinguistics, Egurtzegi's paper nevertheless has linguistic variation in a minority language at its core. The paper analyses the genesis of word-initial aspirated voiceless stops in the three varieties of Basque spoken in France (Eastern Basque). Unlike the Basque varieties of Spain, those of France are severely endangered. The varieties of France are also of interest because they preserve two features considered to be archaic in Basque as a whole: aspirated voiceless stops, and some survival of historical $* \mathrm{~h}$ as /h/. Contemporary Spanish Basque varieties have no aspirated voiceless stops, and have lost 
*h. Word-initial aspirated voiceless stops are argued in the literature to have arisen through a process of anticipatory voicelessness, whereby an original word-initial unaspirated voiced stop, followed in the next syllable by a voiceless stop, becomes voiceless through the spread of [voiced]. Egurtzegi instead proposes that Eastern Basque word-initial aspirated voiceless stops arise by a process of perceptual metathesis, whereby speakers hear aspiration on a stop near the beginning of relevant words, and perceive it as originating on the first stop and not the second. The proposed analysis improves our explanation of the origin of Western Basque wordinitial aspirated voiceless stops in at least three ways. It accounts for an environment where aspiration does not occur (where the voiceless stop in the second syllable is preceded by a sibilant); it makes our account of aspirate dissimilation in Basque more economical, in that it need not now apply in one direction but not the other; and it offers an explanation of seventyyear-old observations of devoiced word-initial lenis stops, which are otherwise difficult to fit into contemporary theory. Once again, then, evidence bearing on old problems in LRs sheds light on modern phonology.

Syntactic theories and methods developed on more major languages have also been tested and extended through application to minority languages. In this issue, as we have seen, Burnett presents a quantitative analysis and syntactic reconstruction of negation markers in moribund oill varieties based on historical evidence. Fifteen years ago, we saw the same in Haddican's syntactic and morphosyntactic work on Basque (Haddican, 2005; 2007). This work has also shown that, notwithstanding the reserve previously expressed about how minoritylanguage communities can be different from majority language ones, some situations can be found where sociolinguistic theory developed on major languages does apply in the minority context. Aurrekoetxea's (2010) computational work for instance shows that there is a demonstrable correlation between non-standard lexicon and non-standard morphology, 
phonology or syntax in different varieties of Basque, as has been demonstrated in more wellstudied languages.

While many of these studies have focused on the oldest generation of LR speakers, a common thread that underpins a body of recent work on LRs relates to learners of threatened minority varieties, too, and their role in shaping the sociolinguistic field.

\section{STANDARDIZATION WITHOUT ACCEPTANCE?}

Much sociolinguistic research has been conducted in societies, often anglophone, where the notion of a standard or prestige variety can be more or less taken as a given. Standard language ideology in western societies is commonly understood to be encultured and propagated by the dominant bloc made up of four key proponents (Education, Media, Entertainment, Industry), who belong to a larger power construct designed to maintain the dominant position of societal elites (Fairclough, 1989; Lippi-Green, 1994). This is particularly true of France, which, it has long been argued, has 'probably the most highly focused society in Europe, with Paris eclipsing regional economic and cultural centres to a greater extent than any other European capital' (Lodge 1993: 228-229, cited in Durand et al. 2013: 66). We need only look at the 2017 row over écriture inclusive, reaching as far as the Prime Minister, to see how attached the French state remains to standardization of the national language (Circulaire du 21 novembre 2017 relative aux règles de féminisation et de rédaction des textes publiés au Journal officiel de la République française; and, for a historical overview; see Schiffman, 1996). The standardization and reification of French in France has gone hand-in-hand with historical attempts to stamp out the varieties previously officially, and still widely unofficially, known as the patois (see de Certeau et al, 1975). These attempts have had profoundly negative consequences for the present state of the underrepresented languages discussed here, even if some commentators (e.g Oakes, 2017) are now more optimistic than they were. It is certainly ironic that, on the one hand, the 
state can be seen as using linguistic purism to justify official hostility to all other languages spoken in the Hexagon, while, on the other, some LR activists can imply that the very same purism is a sine qua non for the LRs' very survival (Woolard, 1998: 18; Hornsby, this volume).

Not all LRs, however, have embraced the notion of a single standard variety. As with all natural languages, France's LRs are all marked by diversity in their vernaculars. In all of these cases, standards do exist (or have been proposed), but they do not always enjoy full acceptance in Haugen's (1966) terms. As LR activists are acutely aware, the stakes are high, and the issues complex. While a standard Breton that enjoyed the acceptance of its Welsh cousin might ensure the medium-term survival of the language, the imposition of a pan-lectal standard variety seen to be the creation of intellectuals might ultimately secure for it a very different fate. Critics of Breton standardization (e.g Jones, 1995) have lamented over-zealous attempts to artificially purify the language by stripping it of its non-Celtic roots, thereby 'distanciating' (Thiers, 1993: 265) it from the bulk of its native speakers and raising the very question of whether an LR standard can ever command widespread acceptance.

The question of who does and does not engage in processes of standardization is, of course, a serious question, which provides the central theme of Lane, Costa, and De Korne's (2018) wide-ranging survey of standardization in minority languages, and is further developed here by a number of our contributors. The difficulty for activists, of course, is standardizing an ' $L$ ' (Low) language in the absence of a recognized and readily available elite model group (higher status individuals being generally the first to abandon L for the economic and social advantages of the 'H' (High) variety). In Haugen's (1966) terms, this generally amounts to standardization without the (spontaneous) selection of norms or acceptance which are usually seen as essential for success. The dilemma is neatly encapsulated by the case of Picard, which is explored from contrasting perspectives in this volume. On the one hand, as Auger and Villeneuve demonstrate, some speakers clearly use and recognize varieties which are 
identifiably Picard, maintaining norms which are distinct from French with respect to a number of grammatical variables shared with the national language. On the other hand, Hornsby argues that internal divisions and long-term convergence with French are now so entrenched, elsewhere in the picardophone area, that the distanciating zeal of activists promoting regionallanguage status impacts negatively in practice on intergenerational transmission, and therefore poses an existential threat to Picard itself. Of course, this dilemma poses further questions when we investigate the effect of standardization on variation: to the extent that standardization is effective, variation should be reduced, so those who engage less deeply with standardization may show more variation in their production patterns and vice versa. Recent research on the production patterns of speakers of standardized varieties, however, does not appear to support this hypothesis.

\section{NÉOLOCUTEURS AS A NEW LR ELITE}

In the context of LRs, we cannot talk about standardization without also talking about people who reside in the areas where these languages are spoken, who may have even been raised in these areas, but who did not grow up speaking the languages: 'Xmen without Xish', in Fishman's terms (Fishman, 1991: 11ff). Such speakers can pose a challenge for standardization efforts, because, for many minority languages, it has been unproblematically assumed that a single standard variety would help learners to learn them. ${ }^{2}$ As outlined above, there is often then the question of which variety of the minority language the standard should be based on. The growing importance of néolocuteurs within these LR communities also poses some fundamental questions about the relationship between these speakers - often young, urban,

\footnotetext{
${ }^{2}$ Even if this is demonstrably false in at least some cases (Drapeau, fc.): literacy is not an antidote to endangerment, nor should it be viewed as such ( $c f$ Fitzgerald, 2017).
} 
well-educated and skilled - and 'traditional' speaker, generally older, often rural-dwelling and/or isolated and working class ( $c f$ Pooley, 2000; Kasstan, 2017).

It is worth pausing on the term néolocuteur, which might be literally translated into English as 'new speaker', a term not without ideological complications (for a discussion, see e.g Hornsby, 2015). This might seem like a neutral label, but it is not so:

the very category of 'new speakers' is one that can lead to contestation, appropriation by those who are indeed concerned (learners of minority languages), but which might also be used by individuals in language movements or in academia, for either descriptive or normative purposes. The 'new speaker' category is not a neutral one [...] (Costa, 2015: 143 on Occitan)

Whatever the terminological problems, Kasstan (2017), in his review of the "new speaker' literature and concept, points out that minority language communities have included people who would now be called 'new speakers' for far longer than the 'new speaker' label has been used in sociolinguistics. The question of new speakers is therefore of enduring and increasing interest in sociolinguistics, as the existence of the EU-funded New Speakers Network and its burgeoning inventory of publications show (COST, 2013).

The discussion around new speakers is significant, as sociolinguistics (notably in its variationist guise) has generally paid little attention to learners. In many ways, First Wave variationist studies had carried on a tradition pursued by Chomsky (and Martinet before him) of totemizing the native speaker as the object of study, even if the analytical lens had shifted from the idiolect to the speech community. Labov has demonstrated that the vernacular as the first learned variety would demonstrate the most systematic patterns of variation, and his principles of linguistic methodology are predicated on the cognitive primacy of the vernacular (e.g Labov, 1971). Since the 1970s, too, the privileged position of the native speaker in sociolinguistics has remained remarkably consistent. What Chambers and Trudgill (1998: 29) 
term NORMs (i.e 'non-mobile older rural males') remains conceptually unchanged from Fishman's (1972: 69) characterization: 'the image of the noble and uncontaminated peasant, who had kept the language pure and intact'. Variationism, which emerged in part at least from a tradition of generativism, has therefore tended to focus on the linguistic practices of native speakers, seeing them as the most traditional, authentic, and legitimate representatives of the speech community (see Bucholtz, 2003). Therefore, conventional wisdom has viewed learners as having little influence on the development of LRs, because of their reliance on artificial standardized varieties which are divorced from those of traditional speakers, and perceived as inauthentic by the latter. In this volume, Kennard considers the context of Breton, where generations of néo-Bretonnants have been raised in the Diwan Breton-medium schooling programme since the 1970s using a modern standardized Breton. As she points out, much of the sociolinguistic work on Breton has focused on interactional analyses comparing the practices and attitudes of traditional Breton speakers and Diwan-educated speakers. In her review of the literature, these néo-Bretonnants are cited as using an artificially restructured language that is inaccessible to those who acquired Breton via more traditional transmission, and these perceived linguistic differences are said to exacerbate community relations. ${ }^{3}$ Such a context does however provide fertile ground on which to test predictions about language production among new speakers: i.e whether they orient to a standard norm against an L1 Breton baseline, or whether they are more influenced by Reference French, given their comparatively limited input within the Diwan setting. In particular, Kennard's paper focuses on how these speakers use impersonal verb constructions and nominal mutations in structured elicitation tasks. Her $\chi^{2}$ analysis reveals only small and subtle differences across speaker types for both variables, which is surprising given the extent of the literature highlighting the

\footnotetext{
${ }^{3}$ A debate that has extended to Breton scholars, too, who can also share in the same subjective and essentialist attitudes e.g Hewitt (2017).
} 
linguistic divides that allegedly distinguish Diwan and non-Diwan-educated Breton speakers (see also Kennard and Lahiri, 2017). Similarly, only little influence from French in the aggregate is observed. Owing to these observations contra the weight of qualitative work on Breton, Kennard's paper illustrates the importance of bridging variationist methodology with research on endangered languages in order to eschew essentializing discourses around nativespeaker ideology. While stylistic variation was not rigorously tested here, there are kernels of evidence to suggest that some instances of variable impersonal forms can be linked with social constructivism, which would constitute further tantalising evidence that new speakers can emerge as important agents of change in endangered-language contexts, playing a more central role than has so far been appreciated in the development and survival of LRs (see Kasstan, 2019 on Francoprovençal).

We alluded above to the absence in minority or threatened language communities of what Trudeau (1992) has termed a norme spontanée, emerging 'naturally' by virtue of an association with a social elite (the Parisian aristocracy in the case of standard French). In the case of LRs, of course, the absence of such an elite deprives the dominated language of a model of 'good' speech around which the speech community can cohere. But, as Kasstan (2019) demonstrates, in the modern, interconnected, digital world, néolocuteurs are able to communicate regularly and rapidly with like-minded individuals across the LR region in question. This contrasts sharply with the usual LR communication habits of many traditional speakers, which are at the level of the village or small town (speakers typically switch to French outside the home domain). Communication over distance, when it occurs in the néolocuteur's L2, can favour pan-regional forms rather than highly localized ones, whether or not these are described or promoted as part of a 'standard' (a label not infrequently rejected by new speakers involved in revitalization movements, as in the case of Francoprocençal). Of course, there is nothing surprising about a preference for pan-regional forms among more mobile speakers with 
looser social networks: witness for example the adoption of supralocal forms in Newcastle, led by younger middle-class women (Milroy et al, 1994). But this development has profound implications in the context of LRs, because evidence, from France and elsewhere, suggests that the social advantages enjoyed by many new-speaker activists lend prestige to the levelled forms that they tend to prefer, in spite of their artificiality from the perspective of older, traditional fluent speakers. ${ }^{4}$ It is ironic that LRs may be finding the elites they have never had, and the bases for future standardization, among the very speakers who might seem superficially to be least equipped to ensure their continued survival.

\section{THE INFLUENCE OF FRENCH ON THE LANGUES RÉGIONALES}

In any context of language contact and shift, there is the potential for the majority language to influence the structure of the minority one, and vice versa. Thomason (2001: 76ff) lists some general tendencies. For her, markedness seems to be the most important factor in determining which structures will be affected. Intensity of contact also plays a crucial role in determining the extent of influence, as does imperfect learning (again of the minority language, in this case). All of these tendencies can be tested in the French situation. There has long been intense contact between the LRs and French, since the LRs now exist in a society which is entirely Frenchspeaking (or has another majority language, for those LRs whose areas cross borders).

The literature contains more research on some LRs than on others, as far as contact with French is concerned. Among the most common outcomes of contact-induced change outlined by Thomason is loss of phonological features; more specifically, 'lost phonemes typically merge with other phonemes rather than disappearing entirely' (2001: 88). To return to Mooney and Hawkey's paper in this volume, the variable production of $/ \AA /$ which they posit to represent

\footnotetext{
${ }^{4}$ On the emergence of urban new-speaker varieties, see e.g on Irish, Ó Murchada (2018), and Scots Gaelic, Nance (2018).
} 
an intermediate stage in the merger of the two phones is also documented in French and other Romance languages. The authors argue that this change has traditionally been interpreted as internally motivated. This then prompts the question of whether or not the variable lateral production in two obsolescing varieties can be attributed to the same cause, or whether external forces associated with language contact can also be predicted to be motivating any shift from the palatal to the median approximant. Their comparative study demonstrates that, while there is advanced merger in both contexts, different explanatory factors emerge from mixed-effects logistic-regression modelling. While contact with French in both cases emerges as an important predictor of merger, the Catalan analysis captures the mechanisms of this change in a more nuanced way. Among the oldest Catalan speakers, the authors demonstrate some evidence that the distributional constraints on [j] in French have been transferred from Catalan and are operating on the merger. However, among the youngest speakers, this change is now progressing independently.

These observations support earlier work on Occitan, too. For instance, Mooney (2017) finds a merger as a result of contact in the Occitan of Occitan-French bilinguals, and provides a further good example of data from underrepresented languages being used to test and advance general linguistic theory, as the merger of Occitan back mid-vowels discussed here is analysed as an example of equivalence classification by speakers who speak both Occitan and French. For Mooney, even though the back mid-vowels of those two languages are not the same, they are similar enough that it is plausible that bilinguals see them as equivalent, if not identical.

Occitan's phonemic inventory (and specifically its lateral consonants) is also the subject of a wide-ranging study by Müller (2011b). In some dialects she finds a shift from $/ \mathfrak{1} /$ towards /1/, and ascribes it to contact not only with French but also with more prestigious varieties of Occitan. We find here an illustration of the pervasive effect of prestige in contact situations, showing that the donor variety in a situation of change does not have to be a more prestigious 
language, but can also be a more prestigious variety of what is still a less prestigious language on the social hierarchy.

Hinzelin (2018), on phonological change in Francoprovençal induced by contact with French, concludes that 'strong and constant pressure from French spanning several centuries' (p. 69) is responsible for certain changes in the Francoprovençal consonant inventory. He notes, importantly, that Francoprovençal is an example of a situation where the contact and resulting change is longer established than might be assumed: evidence again taken from Gilliéron and Edmont (1902-10) shows that some of the changes he documents were underway when the atlas was produced. Coincidentally, one of the changes Hinzelin analyses is in Francoprovençal laterals $(/ K />/ 1 /)$, and Kasstan and Müller (2018), in the same volume, also deals with the levelling of varied surface forms of Francoprovençal $/ K /$. In this volume, both Mooney and Hawkey, and Auger and Villeneuve explore different notions of 'difference' between varieties which are structurally similar. Auger and Villeneuve in particular find examples of similar syntactic constructions in French and in the Picard of the Vimeu region, but find them subject to radically different constraints.

\section{THE SOCIOLINGUISTICS OF FRANCE}

Research of the type we highlight in this issue can also usefully complement existing research on the sociolinguistics of France. Sociolinguistics undertaken in France is heavily biased towards what the Anglo-Saxon tradition often calls 'sociology of language', 'ethnography of communication' or other labels (Coupland and Jaworski, 1997: 1), i.e the investigation of the social positioning and context of languages. As Hymes (1974) remarked nearly half a century ago, it is unhelpful to set up an opposition between this tradition of sociolinguistics and 'quantitative sociolinguistics', because of course sociology of language often uses quantitative measures to compare linguistic practices. However, sociology of language does not use 
instrumental phonetic methods (as variationist sociolinguistics has done since Labov, Yaeger and Steiner, 1972) or, usually, advanced statistical methods (central to variationist methodology since the advent of VARBRUL in the mid-1970s; see Sankoff and Labov, 1979). This leaves a gap for the study of LRs from a variationist perspective, which this volume, among others, is now attempting to bridge, but the difference between the conceptions of 'sociolinguistics' in the English-speaking world and sociolinguistique in France is still striking. It is demonstrated, for example, by the dearth of variationist work on the Hexagon found in the crucial Bibliographie sociolinguistique francophone (see also Durand et al, 2013). We do not mean to suggest that at present there is no research on French sociolinguistics from variationist or other theoretical standpoints, or that there is no sociology of language research in English on the LRs. On the contrary: there has been variationist work on French since Gillian Sankoff's work in the early 1970s, and formal linguistic work on e.g Jersey Norman from at least the late 1950s (e.g Spence, 1957). There has been sociology of language research in English on the LRs since at least Tabouret-Keller (1981), ${ }^{5}$ and much work more recently, as discussed above. But we can at least say that formal-linguistic research in English on the LRs, as in this volume, is comparatively rare, certainly by comparison with the growing interest in formal approaches to variation in dominant-language context (e.g Cornips and Corrigan, 2005). Formal sociolinguistic work on the LRs as presented in this volume, therefore, offers a new dimension to existing research on the sociolinguistics of France, and, more broadly, a contribution to sociolinguistic theory. Though the papers for this volume have been written in English and in some cases adapt and apply models developed in the Anglo-Saxon world, each, in its own way, draws on francophone traditions in what we believe to be a fruitful fusion, which we hope will stimulate further inquiry into what remains a sorely under-researched area.

\footnotetext{
${ }^{5}$ This was a special issue of the International Journal of the Sociology of Language devoted to LRs, but there are also isolated articles in the same journal on individual LRs before then.
} 


\section{NOTE}

We thank the many reviewers for their careful work in helping to deliver the articles presented in this issue, as well as Julia Herschensohn, Nigel Armstrong, and Laurel Preston for their expertise and support throughout the editorial process.

\section{REFERENCES}

Auger, J. and VIlleneuve, A.-J. (2008). Ne deletion in Picard and in regional French: Evidence for distinct grammars. In: M. Meyerhoff and N. Nagy (eds). Social Lives in Language: Sociolinguistics and Multilingual Speech Communities. Amsterdam: John Benjamins, pp. 223-247.

Aurrekoetxea, G. (2010), The correlation between morphological, syntactic and phonological variation in the Basque language. In: B. Heselwood and C. Upton (eds). Proceedings of Methods XIII. Papers form the Thirteenth International Conference on Methods in Dialectology, 2008. Bern: Peter Lang, pp. 207-218.

Bell, A. (2016). Succeeding waves: Seeking sociolinguistic theory for the twenty-first century. In: N. Coupland (ed.), Sociolinguistics: Theoretical Debates. Cambridge: Cambridge University Press, pp. 391-416.

Bucholtz, M. (2003). Sociolinguistic nostalgia and the authentication of identity. Journal of Sociolinguistics, 7(3): 398-416.

Carton, F. (1981). Les parlers ruraux de la région Nord-Picardie: Situation socio-linguistique, International Journal of the Sociology of Language, 29: 15-28.

Cedergren, H. (1973). The interplay of the social linguistic factors in Panama. PhD thesis, Cornell University. 
Certeau, M. de, Julia, D., and Revel, J. (1975). Une politique de la langue. La Révolution française et les patois: l'enquête de Grégoire. Paris: Gallimard.

Chambers, J. K. (1995). Sociolinguistic Theory. Oxford: Blackwell.

Chambers, J. K. and Trudgill, P. (1998). Dialectology. Cambridge: Cambridge University Press.

Chirkova, K., Stanford, J. N. \& D. Wang. (2018). A long way from New York City: Socially stratified contact-induced phonological convergence in Ganluo Ersu (Sichuan China). Language Variation and Change, 30(1): 109-145.

Chomsky, N. (1967). Current Issues in Linguistic Theory. London: Mouton.

Circulaire du 21 novembre 2017 relative aux règles de féminisation et de rédaction des textes publiés au Journal officiel de la République française. Available at: https://www.legifrance.gouv.fr/affichTexte.do?cidTexte=JORFTEXT000036068906 (Accessed: 17 April 2019).

Cornips, L. and Corrigan, K. (eds.) (2005). Syntax and Variation: Reconciling the Biological and the Social. Amsterdam: John Benjamins.

COST (European Cooperation in Science and Technology) (2013). Action IS1306 - New Speakers in a Multilingual Europe - Opportunities and Challenges. Available at: http://www.cost.eu/COST_Actions/isch/IS1306 (Accessed: 17 April 2019).

Costa, J. (2015). New speakers, new language: On being a legitimate speaker of a minority language in Provence. International Journal of the Sociology of Language, 231: 127145.

Coupland, N. and Jaworski, A. (1997). Introduction. In: Coupland, N. and Jaworski, A. (eds.). Sociolinguistics: a reader and coursebook. Basingstoke: Palgrave. pp. 1-3. 
Dow, M. (2014). Contrast and Markedness among Nasal(ized) Vowels: A PhoneticPhonological Study of French and Vimeu Picard. $\mathrm{PhD}$ thesis, Indiana University.

Drapeau, L. (Fc.). Language endangerment and standardization: Perspectives from the Fourth World. In: W. Ayres-Bennett and J. Bellamy (eds.), The Cambridge Handbook of Language Standardisation. Cambridge: Cambridge University Press.

Durand, J., Eychenne, J. and Lyche, C. (2013). On levelling and counter-levelling in French: A phonological perspective. In: M. C. Jones and D. C. Hornsby (eds.), Language and Social Structure in Urban France. Oxford: Legenda, pp. 58-68.

Fairclough, N. (1989). Language and Power. London: Longman.

Fishman, J. A. (1972). Language and Nationalism: Two Integrative Essays. Rowley: Newbury House

Fishman, J. A. (1991). Reversing Language Shift: Theoretical and Empirical Foundations of Assistance to Threatened Languages. Clevedon: Multilingual Matters.

Fitzgerald, C. M. (2017). Understanding language vitality and reclamation as resilience: A framework for language endangerment and 'loss' (Comments on Mufwene). Language 93(4): e281-298.

Gauchat, L. (1905). L’Unité phonétique dans le patois d'une commune. In: Aus Romanischen Sprachen und Literaturen: Festschrift Heinrich Morf. Halle: M Niemeyer, pp. 175232.

Gilliéron, J. and Edmont E. (1902-1910). Atlas linguistique de la France. Paris: Honoré Champion.

Guy, G. and Adli, A. (2019). Workshop on multiculturalism and multilingualism in a megacity, February 21, New York City. 
Haddican, W. (2005). Aspects of language variation and change in contemporary Basque. $\mathrm{PhD}$ thesis, New York University.

Haddican, W. (2007). Suburbanization and language change in Basque. Language in Society, 36(5): 677-706.

Harrison, M. and Joubert, A. (2019). Introduction: Shifting dynamics in French language policies. In: M. Harrison and A. Joubert (eds.), French Language Policies and the Revitalisation of Regional Languages in the 21st Century. Basingstoke: Palgrave Macmillan, pp. 1-34.

Haugen, E. (1966) Dialect, language, nation. American Anthropologist 68: 922-35. Reprinted in Pride, J.B. \& J. Holmes (1972) Sociolinguistics. Harmondsworth: Penguin.

Hendrickson, R. (2013). Distinctive features and the liquids in Picard, Proceedings of the Annual Meetings on Phonology, pp. 1-8.

Hermann, E. (1929) Lautveränderungen in den Individualsprachen einer Mundart: Charmey. Göttingen. Nachrichten von der Gesellschaft der Wissenschaften zu Göttingen, Philologisch-Historische Klasse.

Hewitt, S. (2017). Neo-speakers of endangered languages: Theorizing failure to learn the language properly as creative post-vernacularity. Journal of Celtic Languages, 18(1): 127-154.

Hildebrandt, K. A., Jany, C. \& Silva, W. (2017). Introduction: Documenting variation in endangered languages. Language Documentation \& Conservation, 13: 1-5.

Hinzelin, M.-O. (2018). Contact-induced change in Francoprovençal phonological systems caused by standard French. International Journal of the Sociology of Language, 249: 49-70.

Hornsby, M. (2015). Revitalizing Minority Languages: New Speakers of Breton, Yiddish and Lemko. Basingstoke: Palgrave Macmillan. 
Hymes, D. (1974). The Scope of Sociolinguistics. In Hymes, D. (1974). Foundations in Sociolinguistics: an ethnographic approach. Philadelphia: University of Pennsylvania Press. Reprinted in In Coupland, N. and Jaworski, A. (eds). Sociolinguistics: a reader and coursebook. Basingstoke: Palgrave. pp. 12-22.

Jones, M. C. (1995). At what price language maintenance? Standardization in Modern Breton. French Studies, XLIX(3): 428-436.

Kasstan, J. R. (2017). New speakers: Challenges and opportunities for variationist sociolinguistics. Language and Linguistics Compass, 11(8): e12249.

Kasstan, J. R. and Müller, D. (2018). (1) as a sociolinguistic variable in Francoprovençal. International Journal of the Sociology of Language, 249: 99-118.

Kasstan, J. R. (2019). Emergent sociolinguistic variation in severe language endangerment. Language in Society.

Kennard, H and Lahiri, A. (2017). Mutation in Breton verbs: Pertinacity across generations. Journal of Linguistics, 53(1): 113-145.

Labov, W. (1971). Some principles of linguistic methodology. Language in Society, 1(1): $97-$ 120.

Labov, W. (1994). Principles of Linguistic Change. Volume I: Internal Factors. Oxford: Blackwell.

Labov, W. (2015). The discovery of the unexpected. Asia-Pacific Language Variation, 1(1): $7-22$.

Labov, W. (2016). Afterword: Where are we now? Journal of Sociolinguistics, 20(4): 581-602. Labov, W., Yaeger, M. and Steiner, R. (1972). A Quantitative Study of Sound Change in Progress. 2 vols. Philadelphia, 1972. 
Lane, P., Costa, J. and De Korne, H. (eds.) (2018). Standardizing Minority Languages: Competing Ideologies of Authority and Authenticity in the Global Periphery. London: Routledge.

Lippi-Green, R. (1994). Accent, standard language ideology and discrimination pretext in the courts. Language in Society, 23(2): 163-198.

Meyerhoff, M. (2017). Writing a linguistic symphony: Analyzing variation while doing language documentation. Canadian Journal of Linguistics, 62(4): 525-549.

Meyerhoff, M., Kasstan, J. R. \& U. Horesh (eds.) (Fc.) Style and standards: Sociolinguistics in a global context. Language Ecology.

Milroy, J., Milroy, L., Hartley, S. and Walshaw, D. (1994). (1994). Local and supra-local change in British English: the case of glottalisation. English World-Wide, 15: 1-33.

Ministère de la Culture. (2018). Langues régionales.

http://www.culture.gouv.fr/Thematiques/Langue-francaise-et-langues-de-

France/Politiques-de-la-langue/Langues-de-France/Langues-regionales (Accessed: 17 April 2019).

Mooney, D. (2017). Phonetic transfer in language contact: Evidence for equivalence classification in the mid-vowels of Occitan-French bilinguals. Journal of the International Phonetic Association, 44(3): 1-33.

Müller, D. (2011a). Approches expérimentales en langue minorisée : Le cas de l'occitan. In: C. Blauth-Henke \& M. Heinz (eds.), Où en sont les études des langues régionales en domaine roman ? Données - méthodes - modèles de description. Tübingen: Stauffenburg Verlag, pp. 49-60.

Müller, D. (2011b). Developments of the lateral in Occitan dialects and their Romance and cross-linguistic context. Doctoral dissertation, Universitat de Tolosa 2 - Lo Miralh \& Ruprecht-Karls-Universität Heidelberg. 
Nagy, N. \& Meyerhoff, M. (2008). The social lives of language. In: M. Meyerhoff \& N. Nagy (eds.), Social Lives in Language - Sociolinguistics and Multilingual Speech Communities. Amsterdam: John Benjamins, pp. 1-17.

Oakes, L. (2017). Normative language policy and minority language rights: rethinking the case of regional languages in France. Language Policy, 16(4): 365-384.

Ó Murchada, N. (2018) Renegotiating standard language and language standards in minority contexts. Paper to 'Global approaches to multilingualism and standardisation' conference. University of Cambridge.

Pooley, T. (2000). Sociolinguistics, regional varieties of French and regional languages in France. Journal of French Language Studies, 10(2):117-157.

Roger, G. (2019). The langues de France and the European Charter for Regional or Minority Languages: Keeping Ratification at Bay Through Disinformation: 2014-2015. In: M. Harrison and A. Joubert (eds.), French Language Policies and the Revitalisation of Regional Languages in the 21st Century. Basingstoke: Palgrave Macmillan, pp. 309333.

Sankoff, D. and Labov, W. 1979. On the uses of variable rules. Language in Society 8(2): 189222.

Sankoff, G. 1980 [1976]. The Social Life of Language. Philadelphia: University of Pennsylvania Press.

Schiffman, H. F. (1996). Linguistic Culture and Language Policy. London: Routledge.

Smakman, D. (2015). The westernising mechanism in sociolinguistics. In: D. Smakman and P. Heinreich (eds.), Globalising Sociolinguistics: Challenging and Expanding Theory. London: Routledge, pp. 16-36.

Smith, J.-C. and Maiden, M. (1995). Linguistic Theory and the Romance Languages. Amsterdam: John Benjamins. 
Spence, N. C. W. (1957). L'assibilation de l'r intervocalique dans les parlers jersiais. Revue de linguistique romane, 21: 270-88.

Stanford, J, N. (2016). A call for more diverse sources of data: Variationist approaches in nonEnglish contexts. Journal of Sociolinguistics, 20(4): 525-541.

Stanford, J. N. and Preston, D. (eds.) (2009). Variation in Indigenous Minority Languages. Amsterdam: John Benjamins.

Tabouret-Keller, A. (1981). Introduction. Regional Languages in France: current research in rural situations. International Journal of the Sociology of Language, 29: 5-14.

Thiers, J. (1993). Language contact and Corsican polynomia. In: R. Posner and J. N. Green (eds.), Trends in Romance Linguistics and Philology. Vol 5. Berlin: Mouton de Gruyter, pp. 253-270.

Thomason, S. (2001). Language Contact: An Introduction. Edinburgh: Edinburgh University Press.

Trudeau, D. (1992). Les Inventeurs du Bon Usage (1529-1647). Paris: Minuit.

Trudgill, P. (1999). New-dialect formation and dedialectalisation: Embryonic and vestigial variants. Journal of English Linguistics 27(4): 319-327.

Trudgill, P. (2011). Sociolinguistic Typology. Oxford: Oxford University Press.

Villeneuve, A.-J. and Auger, J. (2013). 'chtileu qu'i m'freumereu m'bouque i n'est point coé au monne': Grammatical variation and diglossia in Picardie. Journal of French Language Studies, 23(1): 109-133.

Vincent, D., Laforest, M., and Martel, G. (1995). Le corpus de Montréal 1995: Adaptation de la méthode d'enquête sociolinguistique pour l'analyse conversationnelle. Dialangue, 6: $29-46$.

Wheeler, M. (1988). Occitan. In: M. Harris and N. Vincent (eds.), The Romance Languages. London: Croom Helm, pp. 246-278. 
Woolard, K. A. (1998). Introduction: Language ideology as a field of inquiry. In: B. B. Schieffelin, K. A. Woolard and P. V. Kroskrity (eds.), Language Ideologies: Practice and Theory. Oxford: Oxford University Press, pp. 3-47. 